\title{
ANALYTICAL MODEL END PLATE BOLTED JOINT UNDER BENDING MOMENT AND AXIAL FORCE LOAD
}

\begin{abstract}
In typical buildings with steel-concrete composite floors, joints are designed to transmit only hogging bending moment. In case of the large horizontal loads due to wind, earthquake or accidental events, sagging bending moments in the joint and not to neglect axial force can also occur. Additionally, large deformations of the structure cause tying and prying effects. The joints loaded in this way are changing their characteristics, and their strength for the bending moment is decreased.

In global analysis of the structures, the accurate knowledge of the characteristics of the joints allows for determine accurate internal forces in the structural elements. Procedures presented in literature and standards [1] allow for appointing of characteristics of the joint only for bending moment without taking into account axial loads.

In the paper, a mechanical model based on "component method" for evaluation of characteristics of the composite joint under bending and axial loads is presented. The influence of tying and prying actions on distribution of the internal forces in a joint is also analyzed. The procedure for calculation of the characteristics of the composite joint with bolted end-plate connection is elaborated too.
\end{abstract}

Keywords: component method, composite joint, analytical model, moment axial force interaction, accidental loads

\section{Introduction}

In typical conditions utylization of buildingl structures, connections of structural elements have established loads so as the bending moment, axial or the transverse force. In case of exceptional or extreme actions, building structures have to perform the robust behaviour. When a column loss occurs due to hazard action such as explosions, impact of vehicle or fire, etc. there should be a possibility of the alternative load path formation through catenary action of the floor members. In such cases, the beam-to-column connections must be able to accommodate excessive sagging deformations and large tie forces.

${ }^{1}$ Author for correspondence: Zdzisław Pisarek, Rzeszów University of Technology, Department of Building Structures. Poznańska 2,35-084 Rzeszów, +17 86516 15. e-mail: pisarzdz@prz.edu.pl 


\section{Resistance of the composite joints}

\subsection{Distribution of internal forces in the joint}

In the service stage of loading, joints ar designed to transfer only bending moments. For analytical model, the bending moment is replace by pair of forces in tension and compression zone. Till concrete slab starts cracking (fig. 1a), tension in the joint is transmitted by the concrete slab and upper bolt row. Usually loading in this stage is large enough that the floor slab cracks. After slab cracking tension is passed to reinforcing bars which elongate with local plastification (fig. 1b).

When accidental action cause column loss, the direction of the loading in the joint change: the steel part of beam-to-column connection is in tension zone and concrete floor slab transfers compression (fig. 1c). Additionally the connection is loaded by forces due of the structure deformation. The global prying action due the rotation of the beam causes the compression in the upper part of joint (fig. 1d). In case of greater deformations the structure changes to mechanism and the beam is stretched by force caused by the effect of the string (tying effect) (fig. 1e).

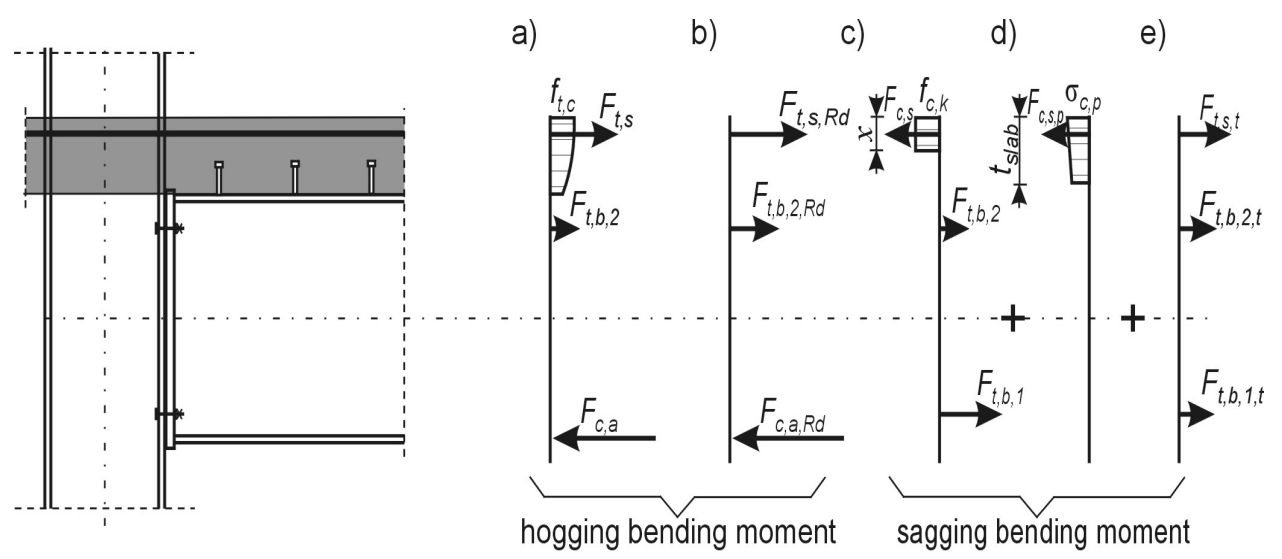

Fig. 1. Distribution of the internal force in composite joint for various phases of loading

Rys. 1. Rozkład sił wewnętrznych w połączeniu zespolonym w różnych fazach obciążenia

An analytical methods presented in Eurocodes [1], [2] (so-called "component method") are devoted to joints subjected to the hogging bending moments. In this method resistance of each zone of the joint is depended on the weakest component.

In joints subjected to the sagging bending moments, steel part of connection is in tension zone and can be analysed using formulae given in [1]. 
Resistance of the compression zone of the joint depends on the strength of the compressed concrete slab. The resistance of the concrete slab in the compression can be estimated by the following formula:

$$
F_{c, s c, R d}=b_{e f f} \cdot \lambda \cdot x \cdot \eta \cdot f_{c d} \cdot \varsigma+F_{c, s, R d}
$$

where $x \quad$ is the effective height of the concrete slab,

$f_{c d} \quad$ is the design compressive strength of concrete,

$\lambda, \eta \quad$ are the factors allowing rectangular stress distribution, and depth of the compression zone according to [3],

$\varsigma \quad$ is the coefficient allowed influence of cracks on compressive strength of concrete,

$F_{c, s, R d}$ is the strength of reinforcement steel bars in compression zone.

Effective width $b_{\text {eff }}$ of the concrete slab according to [2] is depended on the span of adjacent beams and can be calculated as:

$$
b_{e f f}=b_{0}+\sum b_{e i}
$$

$b_{0} \quad$ is the distance between studs,

$b_{e i} \quad$ is the effective width of concrete slab from every side of the beam, equal to $L_{e} / 8$,

$L_{e} \quad$ is the beam equivalent span.

In concrete elements subjected to cyclic variable loads, degradation of strength of the concrete are observed. Decrease of this strength, after the first cycle of load does not exceed 5 percent. Therefore:

$$
\varsigma=\left\{\begin{array}{l}
1,0-\text { for uncracked concrete slab }(\text { Fig. } 1 a) \\
0,95 \text { - for cracked concrete slab }(\text { Fig. } 1 \text { b) }
\end{array}\right.
$$

Reinforcing steel bars which are placed within the range the compression zone of the concrete slab increase slab resistance and can be considered in calculations. The strength of the reinforcement bars can be predicted from:

$$
F_{c, s, R d}=A_{s} \cdot f_{y, s}
$$

where $A_{s}$ is the area of reinforcing bars on the effective width of the concrete slab,

$f_{y, s} \quad$ is the yield strength of steel bars.

Resistance of the compression zone is limited by their depth. The depth of the compression zone is limited by a height of the concrete slab $\left(x \leq t_{\text {slab }}\right)$. 


\subsection{Global prying action}

When the intermediate column is removed due to impact or blast, joint and adjacent beams are subjected to the considerable dislocation. Displacement of the joint causes the rotation of the beam. Elongation of the beam due to rotation (fig. 2) causes compression force (global prying force) in the joint. The value of the prying force is depended on the geometry of the structural system and his stiffness - the stiffer structure is, the prying force increase.

The greatest value the prying force attains at the vertical displacement $\delta$ equal to the total height of the composite beam. In regards to the point of applications, the prying force affect mainly the floor slab. Maximum value of this force can be computed from the formula:

$$
F_{c, p, E d}=\frac{1}{2} \cdot\left(1-\frac{l_{b}}{\sqrt{\left(h_{b}+t_{\text {slab }}\right)^{2}+l_{b}^{2}}}\right)\left(E \cdot\left(A_{s}+A_{b}\right)+E_{c} \cdot b_{\text {eff }} \cdot t_{\text {slab }}\right)
$$

where $A_{b}$ is the cross-section area of the beam,

$h_{b}$ is the height of the beam section,

$t_{\text {slab }}$ is the depth of the concrete slab,

$l_{b} \quad$ is the span of the beam between the columns flanges,

$b_{\text {eff }}, A_{s}, E \quad$ as above.

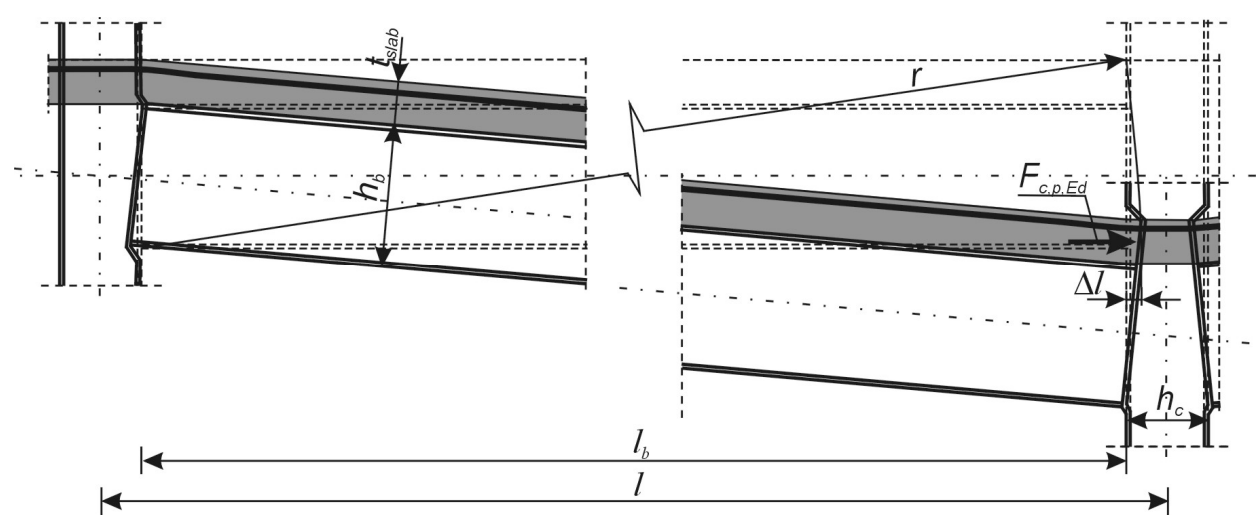

Fig. 2. Schema of generation of global prying force.

Rys. 2. Schemat powstawania globalnej siły sklinowania. 


\subsection{Tying action}

Rules for analyses of the structure using tying method were introduced into the UK Building Regulations [4]. In this approach, all members in the floor structural system are required to be effectively tied together. This method assumes that the accidental loading at the moment of damage equals to the sum of 0,3 imposed load and 1,05 of the dead load. In the service stage the shear force in the joints, calculated using loading equal to the sum of 1,6 imposed load and 1,4 of the dead load is greater than the shear force due to accidental load, so the beams do not fail by shear and the tying force. In practice, there is requirement that the tensile strength of connections is at least equal to the design shear force.

When the intermediate column is removed, adjacent beams and surrounding structural elements should carry current loading trough catenary action. Behaviour of this system is depended on the stiffness and strength of adjacent beams and joints. If joins are stiff enough, the beam become continuous (double span beam). If connections are a simply joints, elements become to tie structure. The scheme of catenary method is shown in fig. 3 .

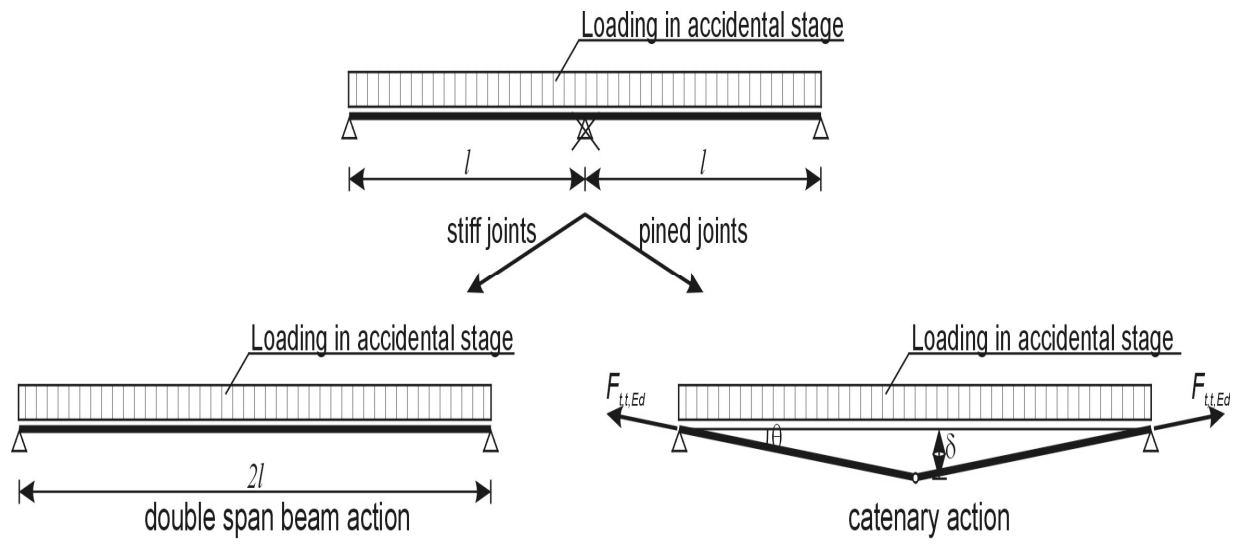

Fig. 3. Schema for analysis of catenary action.

Rys. 3. Schemat powstawania efektu cięgnowego

Shown in fig. 3. simple analytical models corresponded to the structures with ideally stiff elements or with ideally pined joints. In real structure joints neither are nor sufficiently stiff, nor ideally pinned. Therefore axial forces and bending moment in joints in the structure are depended on load and stiffness of the structure. Figure 4, 5 shows relationship between the axial force inducted in the beam, bending moment in the joint and the translation stiffness of the support (weakening column).

This drawings are prepared for beams IPE 300, beam span equal to $6 \mathrm{~m}$ and to the load in accidental stage $15 \mathrm{kN} / \mathrm{m}$. 
Unlike to the global prying force, the tension force due to catenary action is transferred by all joint elements, i.e. all bolt rows and reinforcement bars, proportionally to their stiffness.

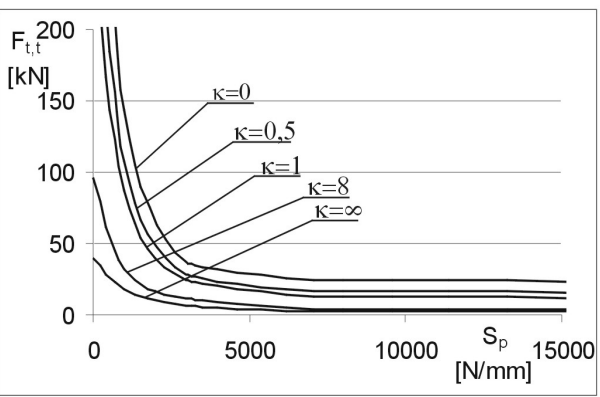

Fig. 4. Support stiffness-tie force relationship.

Rys. 4. Zależność siły efektu cięgnowego od sztywności konstrukcji wsporczej

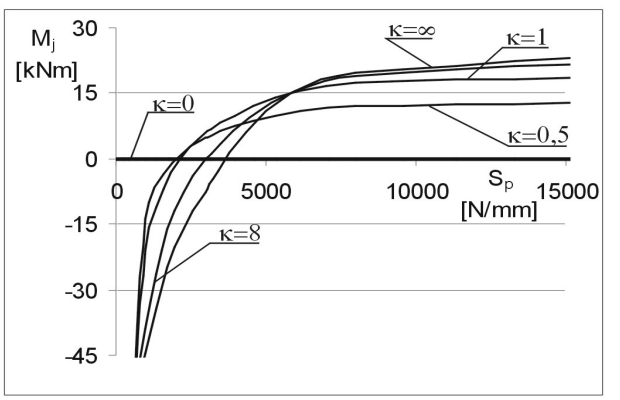

Fig. 5. Support stiffness- moment in the joint relationship.

Rys. 5. Zależność momentu węzłowego od sztywności konstrukcji wsporczej

\section{Initial stiffness of the composite joints}

Calculation of the initial rotational stiffness of the joint requires the knowledge of the stiffness of each component and the position of component in the joint model. The behaviour of each component can be defined as elastic - plastic or rigid-plastic [5]. In connections subjected to the hogging and sagging bending moment, some components of the joint were subjected to opposite direction loading or posses initial deformability due to earlier state of the loading, what should be taken into account.

The proposed component mechanical model for joint subjected to hogging and sagging bending moment is shown in fig. 6 .

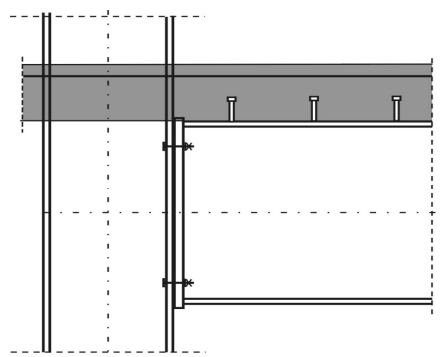

a)

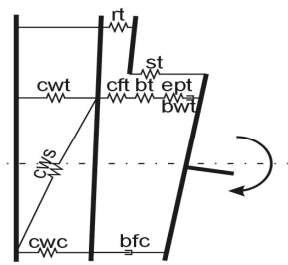

b)

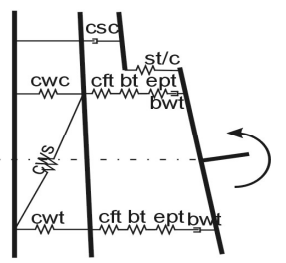

Fig. 6. Proposed mechanical model for composite joint subjected to: a) hogging and b) sagging bending moment

Rys. 6. Proponowany model mechaniczny węzła zespolonego obciążonego: a) ujemnym, i b) dodatnim momentem zginającym 
In joint model under sagging moment the following components should be included: column web in tension (cwt), in compression (cwc) and in shear (cws), column flange in bending (cft), end plate in bending (ept), bolts in tension (bt), beam web in tension (bwt), concrete slab in compression (csc) and shear stud under compression (st/c).

Stiffness coefficients of the most of these components are known and can be adopted from [1].

Concrete slab in compression is usually treated as stiff, and then stiffness coefficient for this element is taken as infinity. However, due to loading of the plate by global prying force, and taking into account slab cracking caused by hogging moment, deformations of the concrete slab must be taken into account in the analytical model. Adopting the formulae given in [6], the coefficient of the stiffness for the concrete slab may be predicted as:

$$
k_{c, s, c}=0,8 \cdot \frac{E_{c}}{E} \cdot \sqrt{b_{e f f} \cdot x}+\frac{w}{s_{r}} \cdot l
$$

where $E_{c} \quad$ is the secant Young modulus for the concrete,

$w \quad$ is the mean crack width under hogging moment,

$s_{r} \quad$ is the maximum crack spacing under hogging moment,

$l \quad$ is the range of hogging moment on the length of the beam,

$b_{\text {eff }}, x, E$ as above.

Stiffness coefficient for shear stud can be adopted as double value of this coefficient obtained for hogging moment.

\section{Influence of the axial force on the joint characteristics}

Axial forces formed as a result of the global prying effect and tying action in the structure additionally loads of the parts of the joint. However they aren't acting in the same time. The value of these forces will depend on the deformation and the stiffness of the structure (fig. 7).

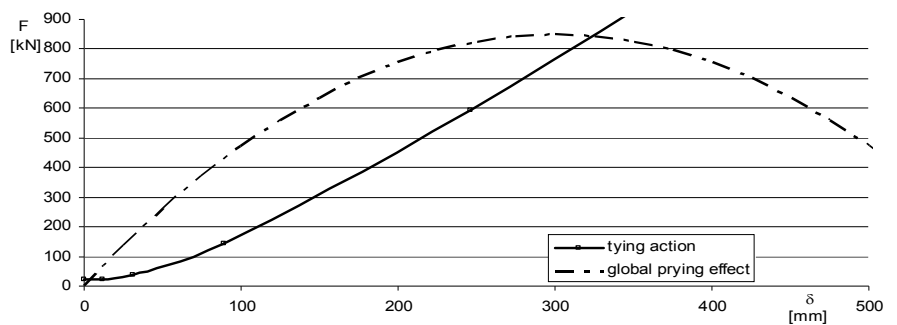

Fig. 7. Vertical displacement - axial force relationship for tying and global prying effect.

Rys. 7. Zależność wartości siły osiowej od pionowego przemieszczenia węzła środkowego. 
These forces are being taken into account according to the outline shown on fig. 1.

\section{Verification of the analytical model of the joint}

For the verification of the model the composite joint was adopted. Dimensions of the joint is presented on fig. 8 .

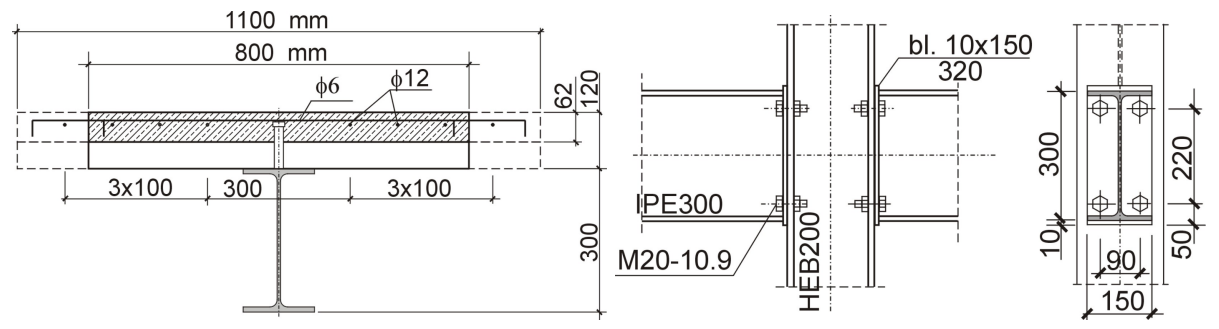

Fig. 8. Dimensions and geometry of the composite joint.

Rys. 8. Wymiary i geometria węzła zespolonego.

Moment resistance of the joint under hogging bending moment amount:

- for uncracked slab:

$$
M_{R d}^{+}=108,1 k N m
$$

- for cracked floor slab:

$$
M_{R d}^{+}=107,8 k N m
$$

Moment resistance of the joint under sagging bending moment amount:

$$
M_{R d}^{-}=99,5 \mathrm{kNm}
$$

Initial stiffness of the joint under hogging bending moment

$$
S_{j, \text { ini }}=260718 \mathrm{kNm} / \mathrm{rad}
$$

Initial stiffness of the joint under sagging bending moment

$$
S_{j, \text { nin }}^{+}=24574 \mathrm{kNm} / \mathrm{rad}
$$


Rotational capacity:

$$
\phi_{j}=0,252 \mathrm{rad}
$$

Moment - rotation characteristics for joint with taken into account axial force is presented on fig. 9.

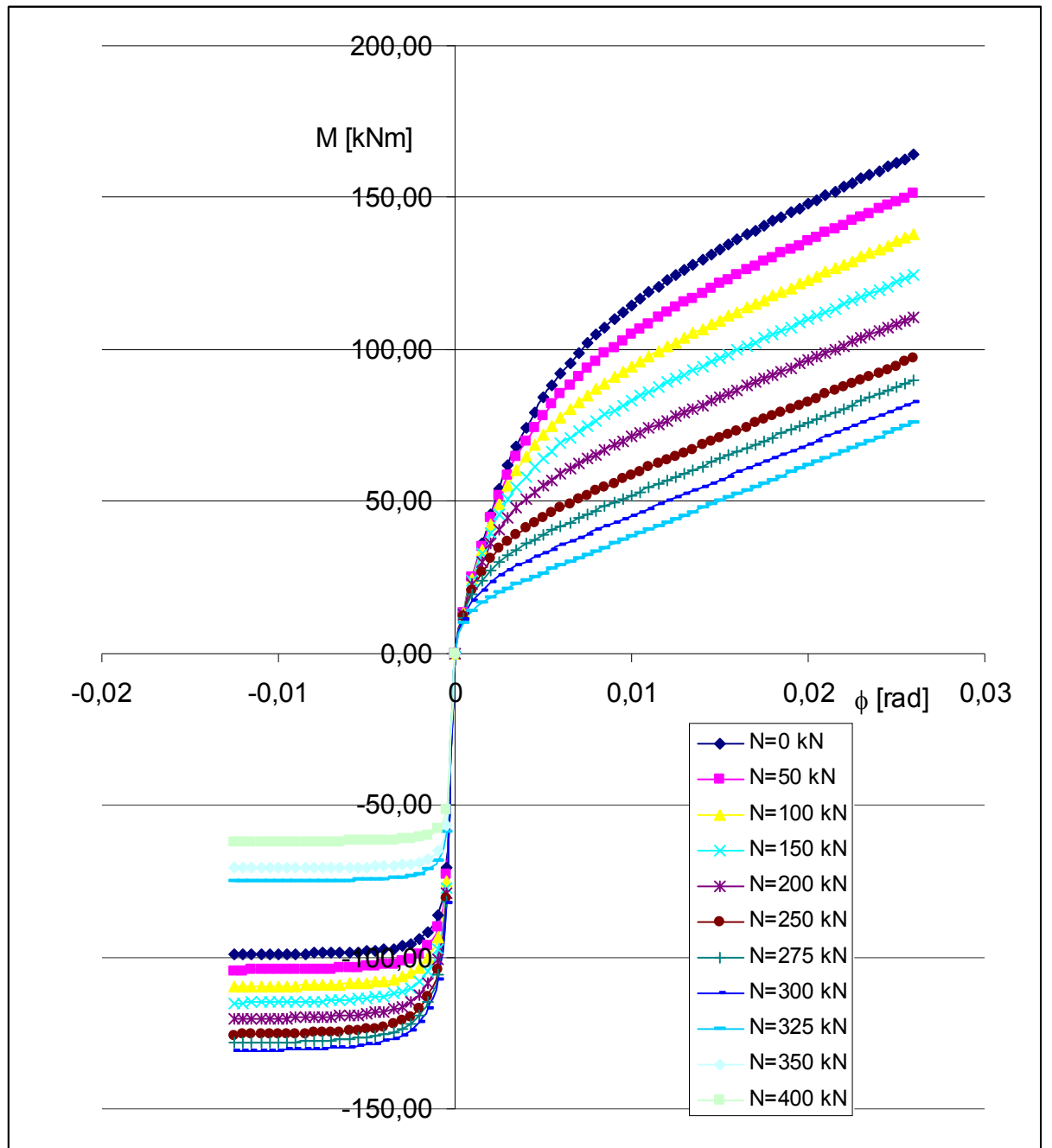

Fig. 9. Moment rotation characteristics of the composite end-plate joint with axial loading.

Rys. 9. Charakterystyka moment - obrót doczołowego węzła zespolonego z uwzględnieniem siły osiowej 
In order to compare the adequacy of the simplified model of the joint a comparative analysis was performed.

Characteristics of the joint are based on the relation moment - rotation including the income of axial force. The curve received in this way from the analytical model was compared with the curve obtained from the experimental research [7].

Moment - rotation characteristics received from experimental test and analytical model is presented on fig. 10. To the description of the joint a Chen function was adopted.

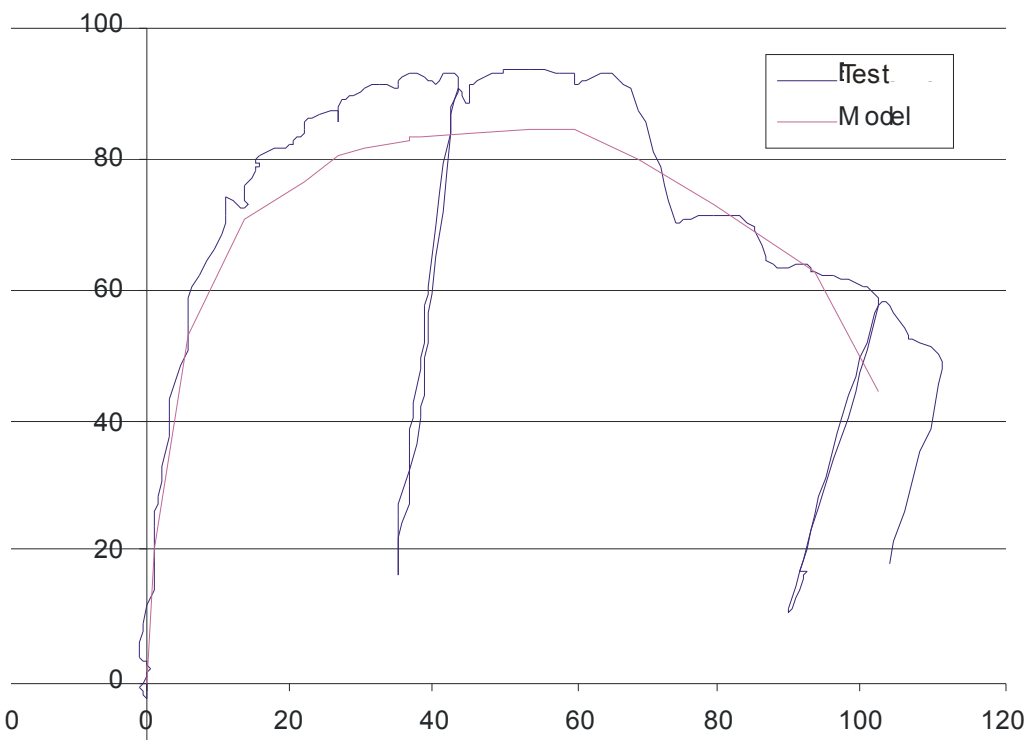

Fig. 10. Comparison of the moment rotation characteristics of the composite end-plate joint received from experimental test and analytical model with taking into account a axial force

Rys. 10. Porównanie charakterystyki momemt - obrót doczołowego węzła zespolonego otrzymanych z badań I modelu analitycznego z uwzględnieniem siły osiowej

\section{Conclusions}

In steel-concrete composite structures joints are as a rule designed for condition of hogging bending moments acting in the joints. In accidental situations, for example when internal column is lost, connections must transfer sagging bending moments. Change of moment direction, forces due to the tying effects and global prying force on distribution of internal forces in the connection and its stiffness should be taken into account 
An analytical model presented in the paper is based on the component method proposed in Eurocodes. This procedure allows additional component of the connection, such as the concrete floor slab in the compression, and influence of the history of loading.

Results obtained from the analytical model relatively well are copying behaviour of real joints.

\section{Bibliography}

[1] PN-EN 1993-1-8 Eurocode 3. Design of Steel Structures. Part 1-8: Design of joints. PKN 2005.

[2] PN-EN 1994-1-1 Eurocode 4. Design of Composite Steel and Concrete Structures. Part 1-1: General rules for buildings. PKN 2008.

[3] PN-EN 1992-1-1 Eurocode 2: Design of concrete structures - Part 1-1: General rules and rules for buildings. PKN 2008.

[4] Byfield, MP, Paramasivam, S, "Issues in the migration of progressive collapse through the tying force method for steel framed buildings with simple connections" Steel and Composite Structures - Wang \& Choi (eds). Taylor \& Francis Group, pp. 267-271, London 2007.

[5] Ahmed, B, Nethercot, DA, "Prediction of initial stiffness and available rotation capacity of major axis flush endplate connections". Journal of Constructional Steel Research Vol. 41. No. 1 pp. 31-60, 1997.

[6] Demonceau, JF, Jaspart, JP, Klinkhammer, R, Oerder, R, Weynand, K, Labory, F, Cajot, LG, "Recent developments on composite connections" Proc Int. Conference EUROSTEEL 2008, pp. 447-452, Graz, 2008.

[7] Kozłowski A., Giżejowski M., Ślęczka L., Pisarek Z., Saleh B., "Experimental investigations of the joint behaviour - Robustness assessement of steel and steelconcrete composite frames", "Eurosteel 2011, 6th European Conference on Steel and Composite Structures, Budapest, Hungary, 31 August - 2 September 2011", 2011

\section{ANALITYCZNY MODEL DOCZOLOWEGO POLĄCZENIA ŚRUBOWEGO OBCIĄŻONEGO MOMENTEM ZGINAJĄCYM I SILĄ OSIOWA}

\section{Streszczenie}

W typowych budynkach ze stropami zespolonymi stalowy-betonowy, węzły są projektowane głownie do przenoszenia momentów zginających. W przypadku dużych obciążeń poziomych powstałych w wyniku oddziaływań wiatru, trzęsień ziemi lub zdarzeń wyjątkowych, w węzłach pojawia się moment dodatni i siła osiowa o niezaniedbywalnej wartości. Dodatkowo, duże odkształcenia konstrukcji mogą wywoływać siłę skleszczenia efekt cięgnowy w ryglach ramy. Obciążone w taki sposób węzły zmieniają swoją charakterystykę, a ich nośność na zginanie maleje. 
W analizie globalnej konstrukcji, znajomość rzeczywistych charakterystyk węzłów pozwala na określenie dokładnego rozkładu sił wewnętrznych w elementach konstrukcji. Procedury przedstawione w literaturze i normie [1] pozwalają na wyznaczanie charakterystyki węzłów jedynie obciążonych momentem zginającym bez uwzględnienia siły osiowej.

W artykule przedstawiono, oparty na metoda składnikowej, model mechaniczny, przydatny do określenia charakterystyki węzła zespolonego poddanego obciążeniu momentem zginającym i siłą osiową. Przeanalizowano również wpływ efektu kleszczenia i efektu cięgnowego na rozkład i wartość sił wewnętrznych w połączeniu. Opracowano procedury do obliczania takich połączeń i na przykładzie wykonano porównanie otrzymanej z modelu charakterystyki węzła z wynikami badań doświadczalnych.

Słowa kluczowe: metoda składnikowa, węzeł zespolony, model analityczny, interakcja moment siła osiowa, obciążenia wyjątkowe

Przestano do redakcji:30.05.2015

Przyjęto do druku:1.12.2015

DOI: $10.7862 / \mathrm{rb} .2015 .158$ 